Hobson, K. A., and K. Kardynal. 2019. Long-term responses of birds to the creation of a community fuel break in the western boreal forest of Canada: implications for management within protected areas. Avian Conservation and Ecology 14(2):5. https://doi.org/10.5751/ACE-01407-140205 Copyright (C) 2019 by the author(s). Published here under license by the Resilience Alliance.

Research Paper

\title{
Long-term responses of birds to the creation of a community fuel break in the western boreal forest of Canada: implications for management within protected areas
}

\author{
Keith A. Hobson ${ }^{1,2}$ and Kevin J. Kardynal ${ }^{1}$ \\ ${ }^{1}$ Environment \& Climate Change Canada, Science and Technology Branch, ${ }^{2}$ Department of Biology, Western University
}

\begin{abstract}
Encroachment, including human settlement, into the North American boreal forest has increased substantially in recent decades. This has resulted in changes in the dynamics, distribution, and functioning of this system with potential negative implications for avifaunal communities. Fuel breaks are often constructed around human settlements in forested landscapes to reduce the potential of damage to infrastructure from wildfires. The frequency and intensity of wildfire in boreal landscapes is projected to increase under future climate change scenarios. Thus, fuel breaks may become a more common management system around communities in the boreal forest. We assessed the responses of 21 bird species to the creation of a fuel break constructed around the village of Waskesiu in Prince Albert National Park, Saskatchewan, Canada. We surveyed birds for 2 years before (2000, 2001) and in 11 of 16 years after clearing $(2002-2017 ; n=14$ sites $)$ relative to reference sites $(n=3$ sites surveyed since 2000 and $n=14$ sites surveyed since 2006$)$. The fuel break ( $247 \mathrm{ha})$ was created in mature aspen-spruce forests and resulted in habitats resembling open parkland and open deciduous forest through removal of $\sim 95 \%$ of the coniferous trees and continuous firebreak management. A community-level analysis indicated that open- and shrub-dwelling bird species became dominant following fuel break creation and for the duration of the study. Individual species-level analyses indicated declines in four avian species associated with older boreal forests (e.g., Bay-breasted Warbler, Setophaga castanea) and increases of six avian species typical of open and shrub habitats (e.g., White-throated Sparrow, Zonotrichia albicollis). However, trends of most species were similar in reference and fuel break sites likely due to the close proximity of reference sites to the fuel break. The fuel break in our study negatively affected most avian species that require older forests and, with ongoing maintenance, fuel breaks represent an unnatural component of the landscape in protected areas. Planned and ongoing expansion of the Waskesiu fuel break and creation of another fuel break (additional 395 ha) in Prince Albert National Park including clearing to protect commercial property outside the park warrant additional investigations into the impacts of fuel breaks on birds and other wildlife.
\end{abstract}

\section{Effets sur les oiseaux de la création d'un coupe-feu près d'un village dans la forêt boréale de l'ouest du Canada : incidences pour l'aménagement dans des aires protégées}

RÉSUMÉ. L'empiètement de la forêt boréale nord-américaine, y compris l'établissement de zones habitées, a augmenté substantiellement dans les récentes décennies, entraînant des changements dans la dynamique, la répartition et le fonctionnement de ce système, et de possibles répercussions négatives sur les communautés d'oiseaux. On construit souvent des coupe-feux autour des zones habitées dans les paysages forestiers pour y réduire le risque de dommages aux infrastructures par les feux de forêt. Selon des scénarios prédisant les effets des changements climatiques futurs, la fréquence et l'intensité des feux de forêt dans les paysages boréaux augmenteront. Les coupe-feux vont dès lors probablement devenir un système de gestion plus commun autour des communautés sises en forêt boréale. Nous avons évalué la tendance de 21 espèces d'oiseaux suivant la construction d'un coupe-feu autour du village de Waskesiu dans le parc national de Prince Albert, en Saskatchewan, Canada. Nous avons inventorié les oiseaux deux ans avant (2000 et 2001) et lors de 11 des 16 ans après la coupe forestière (2002-2017; $\mathrm{n}=14$ sites) comparativement à un site de référence (n $=3$ sites inventoriés depuis 2000 et $n=14$ sites inventoriés depuis 2006). Le coupe-feu ( 247 ha) a été créé dans une forêt de peupliersépinettes mature et les milieux résultant de cet aménagement ressemblaient à de la forêt-parc ouverte et de la forêt décidue ouverte, suivant la coupe de $\sim 95 \%$ des conifères et le maintien en continu de cette zone. Une analyse au niveau de la communauté a révélé que les espèces d'oiseaux de milieux ouverts et arbustifs sont devenues dominantes à la suite de la création du coupe-feu et le sont demeurées tout au long de notre étude. Les analyses au niveau spécifique ont indiqué que quatre espèces d'oiseaux associées aux forêts boréales âgées (p. ex. la Paruline à poitrine baie, Setophaga castanea) ont diminué et que six espèces typiques des milieux ouverts et arbustifs (p. ex. le Bruant à gorge blanche, Zonotrichia albicollis) ont augmenté. Toutefois, la tendance de la plupart des espèces dans les sites de référence était la même que celle des sites localisés dans le coupe-feu, vraisemblablement en raison de la proximité des sites de référence avec le coupe-feu. Le coupe-feu sous étude a affecté négativement la plupart des espèces d'oiseaux qui ont besoin de forêts âgées et, avec leur maintien en continu, les coupe-feux représentent une composante non naturelle dans le paysage d'aires protégées. L'expansion actuelle et planifiée du coupe-feu de Waskesiu et la création prévue d'un autre coupe-feu ( 395 ha) dans le 
parc national de Prince Albert, dont de la coupe forestière en vue de protéger des propriétés commerciales à l'extérieur du parc, méritent un examen approfondi des impacts des coupe-feux sur les oiseaux et les autres espèces fauniques.

Key Words: climate change; forest management; forest retention; forest thinning; fuel break; generalized linear mixed models ( GLMM); Prince Albert National Park

\section{INTRODUCTION}

The southern mixedwood forest within the Boreal Plains Ecozone is the breeding ground for millions of birds and contains some of the most rich and diverse bird communities in North America (Hobson and Bayne 2000a, Wells 2011). Although the majority of the boreal forest remains relatively intact, increasing industrial and commercial development has led to substantial loss and fragmentation of large portions of forest, particularly in the southern part of this biome (Hobson et al. 2002a, Linke and McDermid 2012, Hansen et al. 2013). Indeed, $35 \%$ of the entire Boreal Plains Ecozone remains intact and only $\sim 4 \%$ of this region is protected from direct human disturbance (i.e., as parks; Hobson et al. 2002a, Federal, Provincial, and Territorial Governments of Canada 2010). Therefore, conservation of biodiversity in this ecozone requires effective management of the remaining forests.

Drier conditions and higher tree mortality resulting from climate change have led to increases in the intensity, severity, and frequency of fires in the boreal biome (Michaelian et al. 2011, Peng et al. 2011). These factors, coupled with increased industrialization and urbanization have led to greater humanwildfire interactions in recent decades (Syphard et al. 2007, Kelly et al. 2013, Boucher et al. 2014). Destruction or damage of property, infrastructure, and commercial timber from wildfires carry major social, environmental, and monetary costs; therefore, efforts to minimize risks to these values are often needed.

One approach to reducing wildfire risks to human settlements in forested landscapes is to decrease local fuel availability by creating large breaks in the vegetation surrounding properties that mitigate the spread and intensity of fires. By eliminating or diminishing the potential for crown fires through canopy removal, potential ground fires are expected to be more easily controlled (Agee et al. 2000, Collins et al. 2010). Shaded fuel breaks retain some, often less flammable vegetation as ground cover and deciduous trees to maintain a desirable aesthetic element but may also provide some value as wildlife habitat. Management of shaded fuel breaks through mechanical treatments (e.g., mowing, prescribed burning) is required through time to maintain their effectiveness. However, permanent alteration through recurring management of these areas may reduce their ability to maintain natural habitat for some wildlife, particularly forest specialist species (Hurteau et al. 2008, Burnett et al. 2012).

How birds respond to high levels of forest thinning or clearing and recurring long-term management to reduce fuel loads in the boreal forest is largely unknown. The most relevant analogous situation is in the early seral stages following clear-cut forestry, which results in a dramatic change in forest cover from mature or old-growth forest to open habitat mostly devoid of trees. In the latter scenario, vegetation and bird communities follow predictable shifts from early successional to late seral species and structure through time (Hobson and Bayne 2000a, $b$, Hobson et al. 2000). In contrast, conversion to an open parkland-like habitat and lack of forest regeneration in fuel breaks will likely result in a shift from an avian community dominated by closed canopy forest birds to one dominated by open-habitat generalist or shrubdwelling species (Burnett et al. 2012) persisting through time. Shaded fuel breaks that maintain some vegetation structure (Agee et al. 2000) possibly provide greater benefits to avian and other wildlife communities through availability of more habitat types. Understanding what impacts fuel reduction and fuel break creation and maintenance have on birds can lead to more appropriate management techniques that minimize their impacts on bird communities and vulnerable bird species.

Protected areas such as national parks are important components in the conservation of representative flora and fauna and for serving as benchmarks against human-dominated landscapes (Chape et al. 2005). Indeed, a core mandate of North American national parks is the conservation of native biodiversity through the maintenance of habitats in natural seral stages and insurance against colonization by species associated with other biomes (National Park Service 1916, Government of Canada 2000, Chape et al. 2005, Parks Canada Agency 2008, Sanderson et al. 2012). With increasing recreational usage and development of protected areas, there is a need to incorporate protection of human safety and infrastructure into protected area management. In some Canadian national parks, fuel breaks have recently become used as a means to protect these human values from potentially catastrophic fires. However, fuel breaks are an unnatural component within national parks that may diminish their conservation value and thus not serve as an effective part of protected areas. Consequently, minimizing the impacts of fuel breaks is fundamental to ensuring the objectives of biodiversity conservation in protected areas are met, particularly as threats to these areas intensify from usage, insularization, and climate change (Chape et al. 2005, Wood et al. 2014, 2015).

We assessed responses of individual bird species to the creation of a shaded fuel break in Prince Albert National Park (PANP) in Saskatchewan, Canada. The objectives of this study were to determine changes in bird communities and individual species density before and after construction of a fuel break relative to adjacent or nearby reference forests, ultimately to inform future fuel break development in boreal parks and other forests adjacent to habitation throughout the region. We reasoned that although this was a single event with ongoing management, such manipulations in protected and unprotected areas will become much more common in the future, and deriving avian species responses to these types of management techniques is thus important. Prior to cutting, the fuel break was dominated by oldgrowth ( $>80 \mathrm{yr}$ ) mixedwood, deciduous, or coniferous forests. We expected a change in bird community composition in the fuel break toward an open-habitat, generalist community and a decline in bird species associated with mature or old-growth mixedwood and conifer forests (e.g., Cape May Warbler Setophaga tigrinum). We predicted that the open- and shrubhabitat community would generally persist through time with continued periodic maintenance of the fuel break. 


\section{METHODS}

Our study was conducted near the resort village of Waskesiu $\left(53^{\circ}\right.$ $35^{\prime} 24^{\prime \prime} \mathrm{N}, 106^{\circ} 04^{\prime} 53^{\prime \prime} \mathrm{W}$ ) in PANP, Saskatchewan (Fig. 1). Prince Albert National Park is situated in the Boreal Plains Ecozone (Acton et al. 1998) with the southern part of the park bordering intensive agriculture and the northern portions representing typical boreal forest. Prior to cutting, the forest in the fuel break area was composed of old-growth (> $80 \mathrm{yr})$ mixedwood $(\sim 69 \%)$, hardwood $(\sim 25 \%)$, and pure conifer stands ( $\sim \%$; Prince Albert National Park 2000) dominated by white spruce (Picea glauca), balsam fir (Abies balsamea), trembling aspen (Populous tremuloides), balsam poplar (P. balsamifera), and white birch (Betula papyrifera). A well-developed shrub layer typical of mature boreal forests consisting mainly of green alder (Alnus viridis Chaix), willow (Salix spp.), and hazelnut (Corylus corluta) was also present before fuel break construction (PANP, unpublished data).

Fig. 1. Avian point-count locations in and adjacent a community fuel break created in winter 2001 adjacent to the resort village of Waskesiu in Prince Albert National Park, Saskatchewan, Canada. Point-count stations west and north of the fuel break are from a bird monitoring program initiated in 2006 and used as additional reference sites in this study.

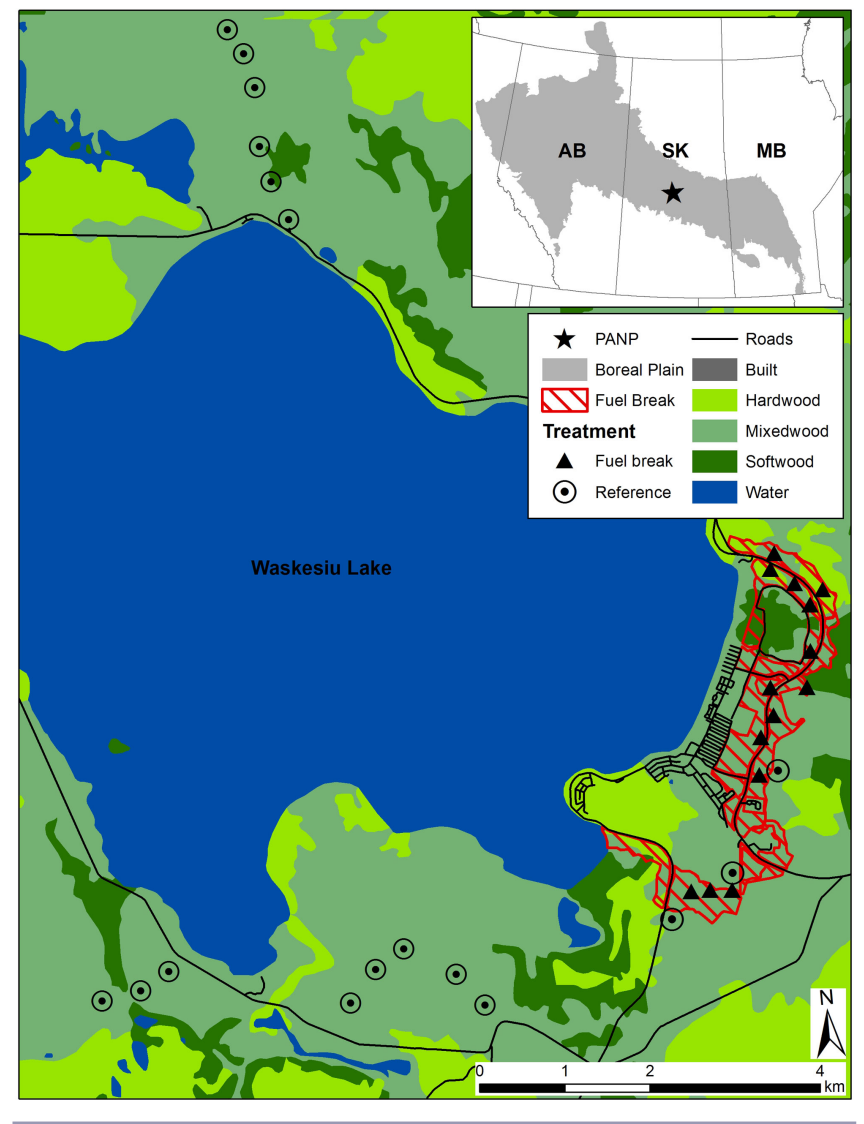

\section{Fuel break creation and management}

Concerns of a potential catastrophic wildfire having an impact on the Waskesiu town site following decades of fire suppression led the Park to create a $\sim 247$ ha (range $\sim 150-600 \mathrm{~m}$ wide) community fuel break (Fig. 1). Removal of greater than $95 \%$ of the conifer trees and selective removal of deciduous trees resulted in $15-95 \%$ tree thinning at individual point-count stations chosen prior to the treatment. The resulting shaded fuel break (hereafter, fuel break) visually resembled open and open deciduousdominated habitats more common in parkland areas south of the park. Initial tree cutting and removal was completed in winter 2002 and subsequent maintenance was done using low-impact techniques to minimize soil compaction and reduce disturbance to understory vegetation (D. Guedo, personal communications). Trees were removed from site and slash from the thinning operation was piled and burned in subsequent years. Annual or semiannual maintenance of the fuel break included piling and burning of slash and deadfall, prescribed fires, and manual brushing to maintain integrity of the fuel break. The fuel break is bordered by mature forest, the village, and Waskesiu Lake.

\section{Bird surveys}

Bird point-count stations were established in 2000 prior to thinning inside (treatment, $\mathrm{n}=14$ ) and adjacent (reference, $\mathrm{n}=$ 3) to the fuel break (Fig. 1). Point-count stations were placed randomly in forest types in approximate proportion to their availability within and adjacent to the fuel break, at least $150 \mathrm{~m}$ from human infrastructure (e.g., roads, village) to minimize their potential influence on bird abundance, and $\sim 300 \mathrm{~m}$ apart to avoid double counting birds. The fuel break boundary was finalized just prior to cutting, and thus several stations initially planned as reference sites were eventually inside the fuel break and so became treatment sites. To increase sample sizes of reference sites, we added 14 point-count locations from a local bird monitoring program that began in 2006. Birds were recorded using two omnidirectional microphones (E3 Biomonitoring System CZM, Riverforks Research Corp (C) in stereo configuration (Hobson et al. 2002b, Campbell and Francis 2011) at each point-count station, and recordings were later analyzed in the lab by three experienced observers. Recorders were deployed manually and each recording was 10 minutes long. Sampling began at sunrise and ended five hours later, and each point count was surveyed once per sampling season. Surveys were completed over two to four days each year from 1 June to 3 July during the peak of the breeding season in the boreal forest. Point-count surveys were conducted for 2 years prior to forest thinning $(2000,2001)$ and for 16 years after thinning until 2017 inclusive except 2007, 2008, 2010, 2015, and 2016. Recordings were made throughout the daily survey period and randomly in thinned and reference sites to reduce the potential influence of time of day on detection probability. All birds heard during the recordings were transcribed and used in analyses because distances cannot be reliably estimated using these recorders (but see Hobson et al. 2002b). Recordings were only made on days with no precipitation and little to no wind.

\section{Habitat surveys}

Residual tree patches remaining after fuel break creation were mapped manually with a geographic information system (GIS) from a high resolution $(15 \mathrm{~cm})$ orthographic photo of the fuel break captured in 2007. Polygons of the fuel break boundary and residual tree patches were constructed by tracing the outer edges of the canopy and converting these to shapefiles. The geographic 
configuration of the fuel break and the remaining residuals have not changed substantially since the construction of the fuel break although tree fall has occurred. The percent area thinned within $150 \mathrm{~m}$ of each point was estimated visually in the field in 2014 . We recorded only coarse vegetation variables to which boreal bird species communities are expected to respond (Bayne et al. 2010).

\section{Data analysis}

\section{Detection probabilities}

We used the QPAD method (Sólymos et al. 2013) to account for varying detection probabilities of birds recorded in our study and to convert abundance data to densities (i.e., birds per point count). Additional details on the QPAD approach can be found in Sólymos et al. (2013). In short, this method combines count removal (Farnsworth et al. 2002) and distance sampling (Buckland et al. $2001)$ approaches to estimate availability $(p)$ and perceptibility $(q)$. Thus, an expected count of a given species can be expressed as: $\mathrm{E}$ $(\mathrm{C})=N p q$, where $\mathrm{N}$ is the true species abundance. Conditional maximum likelihood parameter estimates $(p, q)$ in QPAD are derived from a boreal-wide database of bird count data, which can be applied as offsets in analyses of other datasets. This method incorporates temporal and habitat covariates (e.g., date, time, landcover) from each point-count occurrence to account for detection error. Unlimited distance point-count data, as in our study, are accounted for in QPAD using the effective detection radius (EDR), which is defined as the distance at which as many of the birds are detected beyond the EDR as remain undetected within it (Buckland et al. 2001, Matsuoka et al. 2012, Sólymos et al. 2013).

We included: day of year, time since sunrise, land-cover class (e.g., hardwood, mixedwood, open), percent forest based on survey data and aerial photo queries, point-count duration, and point-count radius (unlimited distance) as covariates in the detection model and incorporated these estimates as offsets in the regression models (Sólymos et al. 2013) and to adjust counts for the multivariate analysis. Further, to reduce variability in detectability, we limited our surveys to the peak of the breeding season, surveyed only until five hours past sunrise when birds are most active defending territories, had only three experienced observers analyze recordings, and surveyed in favorable conditions (e.g., no rain, little or no wind). The QPAD detection probability models were implemented with the "detect" package (Sólymos et al. 2013) in the R computing environment (v3.5.0; R Core Team 2018).

\section{Bird community response}

We used principal response curves (PRC) to assess overall bird community change to creation of the fuel break relative to predisturbance and reference sites. Principal response curves is a multivariate constrained ordination technique similar to redundancy analysis (RDA) and is especially useful for repeated measures time-series data (van den Brink and ter Braak 1999). In PRCs, response curves are produced for each treatment when coefficients are plotted against each time step, which are considered categorical variables. Curves represent divergence in community composition of treatment (i.e., fuel break) sites relative to reference sites and are expressed as canonical coefficients that are derived from weighted multiple regression of sample scores (ter Braak and Smilauer 2002). Weights are calculated for individual species representing their response to treatments with the highest or lowest weights indicating a stronger response to a particular treatment. Species with weights near zero show minimal response to the treatments or a response not definable from the PRC. Significance of the response curves were tested by 9999 permutations of the results against a randomized set of the data. We included species with lower total abundance $(n \geq 25)$ than those analyzed in the GLMM to provide a depiction of the responses of the overall bird community ( $n=25$ species) to creation of the fuel break. We did not include data from the additional 14 reference sites that were surveyed beginning in 2006 because PRC cannot handle missing data. Principal response curves analysis was completed using the "vegan" package (Oksanen et al. 2018) in the R computing environment (R Core Team 2018).

\section{Individual species responses}

We used GLMM to assess responses of 21 individual bird species with $\geq 40$ detections in fuel break and reference sites over the 18year period. These species included interior forest specialist $(\mathrm{n}=$ $6)$, forest generalist $(n=8)$, shrub $(n=4)$, and open $(n=3)$ habitat species (Hobson and Schieck 1999, Hobson and Bayne 2000a). Models were initially fit using Poisson, zero-inflated Poisson, negative binomial, and zero-inflated negative binomial responses of species at each station to several fixed effects and their combinations: (1) year, (2) a factor representing treatment (fuel break (1) vs. reference (0); Treatment), and (3) percent thinning at each station (Thin; Table 1) with treatment included in all models. Outbreaks of spruce budworm (Choristoneura fumiferana) occurred in or near our research site during our study and several bird species have well-documented numerical responses to these outbreaks or to resulting habitat changes (Venier and Holmes 2010). Therefore, we also included models with a fixed effect representing spruce budworm outbreak severity (low or none (0) vs. moderate or high (1)) in our candidate set to account for potential responses to budworm occurrence in five of the sampling years. Additional additive effects of singular variable terms with an interaction term of year with treatment were also included. We initially included several models with second-order polynomial year terms or a log-year term and/or its interaction with treatment; however, they did not have substantial support and were therefore removed from the model set. Individual pointcount stations were modeled as random effects to account for auto-correlated data at the replicate level. A null model (intercept only) was included in the candidate set for a total of 13 models considered for individual species responses (Table 1).

We used Akaike's Information Criterion adjusted for small sample sizes (AICc) to determine which distribution (e.g., Poisson, zero-inflated Poisson) best fit our data and selected the distribution with the lowest AIC $c$ (Warton 2005). Recent research has highlighted issues with estimating model averaged coefficients from regression models with covarying parameters using AIC (Cade 2015) potentially leading to spurious results. Therefore, we selected the most parsimonious model $(\triangle \mathrm{AIC} c=0)$ as the one accounting for the most variance in the data. Finally, model fit was evaluated by assessing normality of residual plots and histograms. Mixed models were fit using the package "glmmTMB" (Magnusson et al. 2017) and AIC $c$ was conducted with the package "bblme" (Bolker and R Development Core Team 2017) in the R statistical computing environment v3.5.0 (R Core Team 2018). 
Table 1. Candidate models used in general linear mixed-models to assess changes in bird density in a community fuel break in Prince Albert National Park two years before cutting $(2000,2001)$ and 16 years after cutting (2002-2017) relative to uncut reference sites. $\mathrm{K}$ is the number of parameters in the model.

\begin{tabular}{|c|c|c|}
\hline Number & Model $^{\dagger}$ & $K$ \\
\hline 1 & Density $\sim$ Intercept & 1 \\
\hline 2 & Density $\sim$ Intercept + Treatment & 2 \\
\hline 3 & Density $\sim$ Intercept + Treatment + Year & 3 \\
\hline 4 & Density $\sim$ Intercept + Treatment + Thin & 3 \\
\hline 5 & Density $\sim$ Intercept + Treatment + Budworm & 3 \\
\hline 6 & Density $\sim$ Intercept + Treatment + Year + Thin & 4 \\
\hline 7 & Density $\sim$ Intercept + Treatment + Thin + Budworm & 4 \\
\hline 8 & Density $\sim$ Intercept + Treatment + Year + Budworm & 4 \\
\hline 9 & Density $\sim$ Intercept + Treatment + Year + Thin + Budworm & 5 \\
\hline 10 & Density $\sim$ Intercept + Treatment + Year + Treatment $*$ Year & 4 \\
\hline 11 & Density $\sim$ Intercept + Treatment + Year + Thin + Treatment $*$ Year & 5 \\
\hline 12 & Density $\sim$ Intercept + Treatment + Year + Budworm + Treatment* Year & 5 \\
\hline 13 & Density $\sim$ Intercept + Treatment + Year + Thin + Budworm + Treatment $*$ Year & 6 \\
\hline
\end{tabular}

'Budworm: Presence of budworm (factor: none, low vs. moderate, high) overlapping point-count stations in a given year. Thin: scaled percent forest thinned within $150 \mathrm{~m}$ of point Density station (scaled to 0 mean and 1SD).

Treatment: fuel break vs. reference.

Year: scaled to 1 (i.e., $2000,2001=1,2002=2,2003=3$ ).

\section{RESULTS}

\section{Bird community response}

The PRC contrasting the time series data of bird densities in the fuel break relative to reference sites was significant $\left(\mathrm{F}_{1,177}=6.39\right.$, $p<0.01)$ indicating substantial changes in the bird community over time. Overall, the community shifted toward open and shrubdwelling species dominating the fuel break (Fig. 2). The first two ordination axes explained $41.7 \%$ and $14.5 \%$ of the variance of the species-environment relationship, respectively. Canonical coefficients of the bird community in the fuel break were most similar in the two years precutting (coefficients $=-0.13$ and -0.05 , respectively; Fig. 2). As shown by the PRC, differences in community composition were evident prior to cutting in the first two years of the study; however, divergence in the bird community apparently remained relatively stable following fuel break clearing and divergence was highest in 2006 (canonical coefficient $=-0.39$ ) and at the end of the study (2017; canonical coefficient $=-0.38)$. Overall, mean PRC scores for birds (see right y-axis of Fig. 2) were for positive interior forest-dwelling species (mean $=0.58$ $\pm 0.44 \mathrm{SD}$; i.e., negative response to fuel break), near 0 for forest generalists (mean $=-0.01 \pm 0.49$; neutral response), and negative for open and shrub-dwelling (mean $=-0.48 \pm 0.49$; positive response) species (Table 2). Mature forest species (e.g., Baybreasted Warbler Setophaga castanea, Ovenbird Seiurus aurocapilla) had the highest PRC scores (i.e., negative response) and open and shrub-habitat species (e.g., White-throated Sparrow Zonotrichia albicollis) had the lowest PRC scores (i.e., positive response).

\section{Individual species responses}

Several models fit with a negative binomial distribution had issues with convergence and otherwise models fit with a Poisson distribution outcompeted zero-inflated Poisson models for all species based on $\triangle \mathrm{AIC} c$ (normal Poisson models had lower $\mathrm{AIC} c$ ). Therefore, we used the Poisson family for all GLMMs. The null model was the top model $(\Delta \mathrm{AIC} c=0)$ only for Blue-
Fig. 2. First axis of the principal response curve (PRC) showing changes in community composition of 25 bird species at pointcounts in response to fuel break construction $(n=14)$ relative to reference sites $(n=3)$ in Prince Albert National Park,

Saskatchewan, two years $(2000,2001)$ prior to cutting and 16 years after cutting (2002-2017). The dashed red line represents change in community composition of treatment sites (i.e., fuel break) relative to reference sites and are expressed as canonical coefficients, which are derived from weighted multiple regression of sample scores. The affinity of each species (tick marks) to the reference and fuel break treatments is represented as weights and is shown on the right side of the figure. The vertical dashed line represents the date of fuel break creation. Species codes, common and scientific names, and individual species' PRC scores are shown in Table 2.

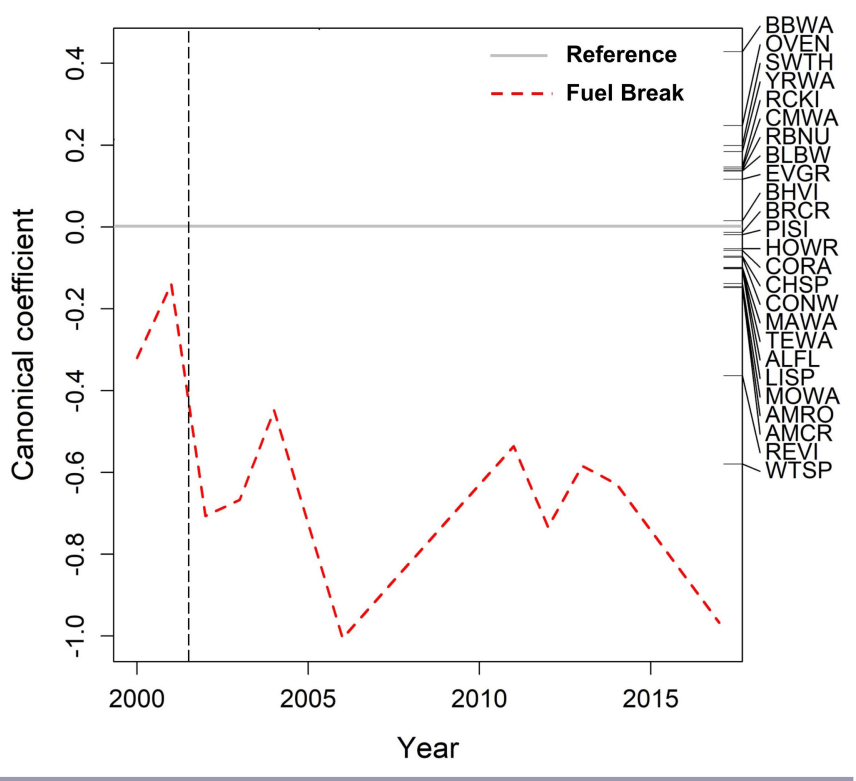


Table 2. Individual species scores (canonical coefficient) from the principal response curve (PRC) analysis of point-count surveys in fuel break $(n=14)$ and reference sites $(n=3)$ in Prince Albert National Park, Saskatchewan, two years $(2000,2001)$ prior to cutting and 16 years after cutting (2002-2017). Higher scores indicate affinity to uncut reference sites and lower (i.e., negative) scores indicate preference for fuel break sites. Species codes are used in Fig. 2.

\begin{tabular}{lllll}
\hline \hline Code & Common Name & Scientific Name & Habitat & Canonical Coefficient \\
\hline ALFL & Alder Flycatcher & Empidonax alnorum & -0.308 \\
AMCR & American Crow & Corvus brachyrhynchos & Shrub & -0.447 \\
AMRO & American Robin & Turdus migratorius & Open & -0.441 \\
BBWA & Bay-breasted Warbler & Setophaga castanea & Open & 1.295 \\
BHVI & Blue-headed Vireo & Vireo solitaries & Forest interior & 0.046 \\
BLBW & Blackburnian Warbler & Setophaga fusca & Forest generalist & 0.413 \\
BRCR & Brown Creeper & Certhia Americana & Forest interior & -0.040 \\
CHSP & Chipping Sparrow & Spizella passerine & Forest interior & -0.215 \\
CMWA & Cape May Warbler & Setophaga tigrinum & Forest generalist & 0.429 \\
CONW & Connecticut Warbler & Oporornis agilis & Forest interior & -0.223 \\
CORA & Common Raven & Corvus corax & Forest generalist & -0.174 \\
EVGR & Evening Grosbeak & Coccothraustes vespertinus & Open & 0.354 \\
HOWR & House Wren & Troglodytes aedon & Forest generalist & -0.161 \\
LISP & Lincoln's Sparrow & Melospiza lincolnii & Open & -0.309 \\
MAWA & Magnolia Warbler & Setophaga magnolia & Shrub & -0.298 \\
MOWA & Mourning Warbler & Geothlypis philadelphia & Shrub & -0.418 \\
OVEN & Ovenbird & Seiurus aurocapilla & Shrub & 0.750 \\
PISI & Pine Siskin & Spinus pinus & Forest interior & -0.057 \\
RBNU & Red-breasted Nuthatch & Sitta canadensis & Forest generalist & 0.417 \\
RCKI & Ruby-crowned Kinglet & Regulus calendula & Forest generalist & 0.443 \\
REVI & Red-eyed Vireo & Vireo olivaceus & Forest generalist & -1.098 \\
SWTH & Swainson's Thrush & Catharus ustulatus & Forest generalist & 0.601 \\
TEWA & Tennessee Warbler & Oreothlypis peregrina & Forest interior & -0.301 \\
WTSP & White-throated Sparrow & Zonotrichia albicollis & Forest generalist & -1.751 \\
YRWA & Yellow-rumped Warbler & Setophaga coronate & Open & 0.556 \\
\hline & & & Forest generalist &
\end{tabular}

headed Vireo (Vireo solitarius) indicating a lack of support for the selected independent variables.

Based on the most parsimonious models from our GLMM analysis (selected using $\triangle \mathrm{AIC} c$ ) of individual species, 6 of 21 species had decreasing trends over the study period with many forest specialists and forest generalists declining (Table 3; Fig. 3). Species with the greatest declines generally require mature interior forested habitats for breeding (e.g., Bay-breasted Warbler; Fig. 3). However, most species that declined in the fuel break had comparable declines in reference sites. Similarly, several forest generalist species (Yellow-rumped Warbler Setophaga coronata) also declined following fuel break construction (Fig. 4). Six of the remaining species, which were typically associated with openshrub and open-forest habitats increased following fuel break construction including Lincoln's Sparrow (Melospiza lincolnii) and Magnolia Warbler (Setophaga magnolia; Fig. 5). Many of these species were essentially absent before creation of the fuel break. Several of these species also increased in reference sites potentially indicating broader-scale effects of the fuel break on adjacent forests (i.e., where reference sites were situated).

\section{DISCUSSION}

The use of vegetation breaks as a tool for managing fuel loads to reduce potential wildfire intensity and severity near settlements is relatively new and uncommon in the boreal forest. Construction and ongoing management (e.g., clearing, prescribed fire) of the fuel break in Prince Albert National Park created a parkland-like environment through removal of the majority $(\sim 95 \%)$ of coniferous trees and selective removal of deciduous trees. Conversion from mature conifer and mixedwood forest was paralleled by abrupt declines in bird communities and species associated with these habitats (e.g., Bay-breasted Warbler, Cape May Warbler). In contrast, fuel break construction and maintenance resulted in increases in open- and shrub-dwelling species (e.g., White-throated Sparrow, Lincoln's Sparrow) and some open forest-dwelling species (e.g., Connecticut Warbler Oporornis agilis), many of which are more common across various successional stages. Fuel breaks may be a useful management tool for protecting human habitations in the boreal forest; however, they represent an unnatural habitat type for boreal specialist birds. Thus, creation and management of fuel breaks inside national parks may not align with the goal of biodiversity conservation in protected areas particularly when attempting to conserve forest specialist species.

A paucity of fuel break studies in the boreal forest limits comparisons with other research to similar studies in other forested biomes and to analogous human disturbances in the boreal forest (e.g., forestry). In general, our results agree with fuel break studies in the western and southern United States in which large declines in mature forest nesting bird species and increases in abundance of edge and open-habitat species were observed following fuel break construction (Hurteau et al. 2008, Burnett et al. 2012). Our study site most closely resembled physical attributes of recent (e.g., 1-5 yr postharvest) clear-cuts in which removal of the majority of trees has created an open shrub- or 
Avian Conservation and Ecology 14(2): 5

Table 3. Coefficients, standard errors $( \pm 1 \mathrm{SE}), \mathrm{Z}$ and $\mathrm{p}$-values for parameters from the most parsimonious model selected using $\triangle \mathrm{AICc}($ i.e., $\triangle \mathrm{AICc}=0$ ) from generalized linear mixed effects model $(\mathrm{GLMM})$ analysis assessing changes in density for 21 bird species 2 years prior to $(2000,2001)$ and 16 years $(2002-2017)$ after creation of a fuel break in Prince Albert National Park, Saskatchewan (see Methods). Scientific names are listed in Table 2.

\begin{tabular}{|c|c|c|c|c|c|c|c|}
\hline \multirow[b]{2}{*}{ Species } & \multirow[b]{2}{*}{ Variable } & \multicolumn{6}{|c|}{ Fixed effects } \\
\hline & & $\beta$ & SE & LCI & UCI & $\mathrm{Z}$ & $\mathrm{P}$ \\
\hline \multirow[t]{4}{*}{ Alder Flycatcher } & Intercept & -7.06 & 0.81 & -8.23 & -5.89 & - & - \\
\hline & Treatment & -0.90 & 1.50 & -3.06 & 1.26 & -0.60 & 0.55 \\
\hline & Year & 0.13 & 0.03 & 0.085 & 0.18 & 3.88 & $<0.001$ \\
\hline & Thin & 4.85 & 2.03 & 1.93 & 7.77 & 2.39 & 0.02 \\
\hline \multirow[t]{4}{*}{ American Robin } & Intercept & -1.99 & 0.28 & -2.39 & -1.59 & - & - \\
\hline & Treatment & 0.96 & 0.34 & 0.47 & 1.45 & 2.80 & 0.01 \\
\hline & Year & -0.02 & 0.02 & -0.04 & 0.01 & -1.01 & 0.31 \\
\hline & Thin & -0.43 & 0.33 & -0.91 & 0.04 & -1.31 & 0.19 \\
\hline \multirow[t]{6}{*}{ Bay-breasted Warbler } & Intercept & -0.75 & 0.54 & -1.52 & 0.03 & - & - \\
\hline & Treatment*Year & -0.18 & 0.06 & -0.27 & -0.10 & -3.13 & 0.002 \\
\hline & Treatment & 1.60 & 0.59 & 0.75 & 2.46 & 2.69 & 0.007 \\
\hline & Year & -0.005 & 0.04 & -0.06 & 0.05 & -0.14 & 0.89 \\
\hline & Thin & -1.49 & 0.40 & -2.07 & -0.91 & -3.70 & $<0.001$ \\
\hline & Budworm & 0.49 & 0.34 & 0.003 & 0.98 & 1.45 & 0.15 \\
\hline \multirow[t]{3}{*}{ Blackburnian Warbler } & Intercept & -2.14 & 0.45 & -3.02 & -1.26 & - & - \\
\hline & Treatment & 0.85 & 0.63 & -0.39 & 2.08 & 1.34 & 0.18 \\
\hline & Thin & -1.62 & 0.57 & -2.74 & -0.50 & -2.84 & 0.005 \\
\hline \multirow{2}{*}{ Blue-headed Vireo } & Intercept & -2.21 & 0.19 & -2.48 & -1.93 & - & - \\
\hline & Treatment & 0.17 & 0.26 & -0.20 & 0.54 & 0.66 & 0.51 \\
\hline \multirow{2}{*}{ Brown Creeper } & Intercept & -0.66 & 0.13 & -0.85 & -0.48 & - & - \\
\hline & Treatment & 0.49 & 0.16 & 0.26 & 0.73 & 3.02 & 0.003 \\
\hline \multirow[t]{3}{*}{ Chipping Sparrow } & Intercept & -1.15 & 0.15 & -1.37 & -0.94 & - & - \\
\hline & Treatment & 0.36 & 0.18 & 0.10 & 0.62 & 1.98 & 0.05 \\
\hline & Budworm & 0.50 & 0.15 & 0.28 & 0.72 & 0.001 & 0.04 \\
\hline \multirow[t]{5}{*}{ Cape May Warbler } & Intercept & -0.03 & 0.58 & -0.87 & 0.80 & - & - \\
\hline & Treatment & 0.04 & 0.39 & -0.53 & 0.60 & 0.09 & 0.93 \\
\hline & Year & -0.11 & 0.05 & -0.19 & -0.04 & -2.19 & 0.03 \\
\hline & Thin & -1.51 & 0.41 & -2.11 & -0.92 & -3.67 & $<0.001$ \\
\hline & Budworm & 1.18 & 0.48 & 0.48 & 1.87 & 2.44 & 0.01 \\
\hline \multirow[t]{4}{*}{ Connecticut Warbler } & Intercept & -4.07 & 0.45 & -4.72 & -3.43 & - & - \\
\hline & Treatment & 0.88 & 0.32 & 0.42 & 1.34 & 2.74 & 0.01 \\
\hline & Year & 0.13 & 0.03 & 0.09 & 0.17 & 4.48 & $<0.001$ \\
\hline & Budworm & -0.89 & 0.65 & -1.83 & 0.05 & -1.36 & 0.17 \\
\hline House Wren & Intercept & -0.40 & 1.21 & -2.14 & 1.33 & - & - \\
\hline & Treatment*Year & 0.31 & 0.18 & 0.05 & 0.56 & 1.74 & 0.08 \\
\hline & Treatment & -3.12 & 1.21 & -4.86 & -1.38 & -2.58 & 0.01 \\
\hline & Year & -0.50 & 0.18 & -0.76 & -0.25 & -2.87 & 0.004 \\
\hline & Thin & 4.42 & 1.41 & 2.40 & 6.44 & 3.15 & 0.002 \\
\hline & Budworm & -1.83 & 0.56 & -2.64 & -1.03 & -3.28 & 0.001 \\
\hline Lincoln's Sparow & Intercept & -5.41 & 0.77 & -6.52 & -4.29 & - & - \\
\hline & Treatment & -0.91 & 1.04 & -2.41 & 0.58 & -0.88 & 0.38 \\
\hline & Year & 0.06 & 0.03 & 0.01 & 0.11 & 1.86 & 0.06 \\
\hline & Thin & 4.36 & 1.44 & 2.28 & 6.44 & 3.02 & 0.003 \\
\hline & Budworm & -1.92 & 1.04 & -3.42 & -0.43 & -1.86 & 0.06 \\
\hline Magnolia Warbler & Intercept & -2.30 & 0.53 & & & - & - \\
\hline & Treatment*Year & 0.20 & 0.05 & 0.12 & 0.27 & 3.87 & $<0.001$ \\
\hline & Treatment & -1.66 & 0.72 & -2.70 & -0.62 & -2.30 & 0.02 \\
\hline & Year & 0.03 & 0.04 & -0.03 & 0.08 & 0.68 & 0.50 \\
\hline Mourning Warbler & Intercept & -2.99 & 0.40 & -3.57 & -2.41 & - & - \\
\hline & Treatment & 0.50 & 0.35 & -0.01 & 1.00 & 1.40 & 0.16 \\
\hline & Year & 0.07 & 0.03 & 0.03 & 0.11 & 2.62 & 0.01 \\
\hline & Budworm & -0.76 & 0.48 & -1.45 & -0.06 & -1.57 & 0.12 \\
\hline Ovenbird & Intercept & -0.03 & 0.14 & -0.23 & 0.17 & - & - \\
\hline & Treatment & -0.10 & 0.23 & -0.44 & 0.24 & -0.43 & 0.67 \\
\hline & Thin & -1.72 & 0.21 & -2.03 & -1.42 & -8.12 & $<0.001$ \\
\hline Red-breasted Nuthatch & Intercept & -0.36 & 0.28 & -0.76 & 0.04 & - & - \\
\hline & Treatment & -0.21 & 0.30 & -0.64 & 0.23 & -0.68 & 0.49 \\
\hline & Year & -0.16 & 0.03 & -0.20 & -0.12 & -5.51 & $<0.001$ \\
\hline & Thin & -0.89 & 0.38 & -1.43 & -0.35 & -2.37 & 0.02 \\
\hline Red-eyed Vireo & Intercept & -2.07 & 0.33 & -2.43 & -1.50 & - & - \\
\hline & Treatment*Year & -0.06 & 0.03 & -0.10 & -0.01 & -2.13 & 0.03 \\
\hline & Treatment & 0.86 & 0.38 & 0.05 & 0.13 & 2.28 & 0.02 \\
\hline & Year & 0.09 & 0.03 & 0.66 & 1.76 & 3.74 & $<0.001$ \\
\hline & Budworm & 0.24 & 0.22 & -1.02 & -0.20 & 1.10 & 0.27 \\
\hline
\end{tabular}

(con'd) 


\begin{tabular}{|c|c|c|c|c|c|c|c|}
\hline \multirow[t]{3}{*}{ Ruby-crowned Kinglet } & Intercept & -2.29 & 0.36 & -2.80 & -1.78 & - & - \\
\hline & Treatment & 0.56 & 0.54 & -0.21 & 1.33 & 1.04 & 0.30 \\
\hline & Thin & -1.47 & 0.47 & -2.14 & -0.80 & -3.15 & 0.002 \\
\hline \multirow[t]{5}{*}{ Swainson's Thrush } & Intercept & -1.17 & 0.34 & -1.66 & -0.67 & - & - \\
\hline & Treatment*Year & -0.13 & 0.06 & -0.22 & -0.04 & -2.12 & 0.03 \\
\hline & Treatment & -0.01 & 0.03 & -0.05 & 0.03 & -0.50 & 0.62 \\
\hline & Year & 0.359 & 0.43 & -0.26 & 0.98 & 0.83 & 0.40 \\
\hline & Thin & -1.91 & 0.48 & -2.60 & -1.21 & -3.96 & $<0.001$ \\
\hline \multirow[t]{4}{*}{ Tennessee Warbler } & Intercept & 1.18 & 0.10 & 1.04 & 1.32 & - & - \\
\hline & Treatment & -0.06 & 0.12 & -0.23 & 0.11 & -0.53 & 0.60 \\
\hline & Year & -0.03 & 0.01 & -0.05 & -0.02 & -4.01 & $<0.001$ \\
\hline & Thin & -0.78 & 0.14 & -0.98 & -0.57 & -5.46 & $<0.001$ \\
\hline \multirow[t]{5}{*}{ White-throated Sparrow } & Intercept & -1.23 & 0.17 & -1.47 & -0.99 & - & - \\
\hline & Treatment & -0.65 & 0.31 & -1.09 & -0.21 & -2.11 & 0.03 \\
\hline & Year & 0.03 & 0.01 & 0.02 & 0.05 & 3.14 & 0.002 \\
\hline & Thin & 1.69 & 0.38 & 1.15 & 2.24 & 4.49 & $<0.001$ \\
\hline & Budworm & -0.56 & 0.19 & -0.83 & -0.28 & -2.92 & 0.003 \\
\hline \multirow[t]{5}{*}{ Yellow-rumped Warbler } & Intercept & 0.62 & 0.28 & 0.21 & 1.02 & - & - \\
\hline & Treatment*Year & 0.08 & 0.03 & 0.03 & 0.13 & 2.48 & 0.01 \\
\hline & Treatment & -0.39 & 0.34 & -0.87 & 0.10 & -1.15 & 0.25 \\
\hline & Year & -0.11 & 0.03 & -0.15 & -0.07 & -4.26 & $<0.001$ \\
\hline & Thin & -0.83 & 0.28 & -1.23 & -0.43 & -2.99 & 0.003 \\
\hline
\end{tabular}

Fig. 3. Responses of forest interior bird species to the creation of a community fuel break in Prince Albert National Park, Saskatchewan. Point-count surveys were conducted two years before $(2000,2001)$ and 16 years after $(2002-2017)$ creation of the fuel break ( $\mathrm{n}=14$ sites) and in undisturbed reference sites $(n=3)$. Additional reference sites $(n=14)$ from a local bird monitoring project that began in 2006 were also included. Error bands represent $85 \%$ confidence intervals. The vertical dashed line represents the date the fuel break was constructed. Annual mean abundance values for fuel break and reference sites are shown as crosses and circles, respectively.

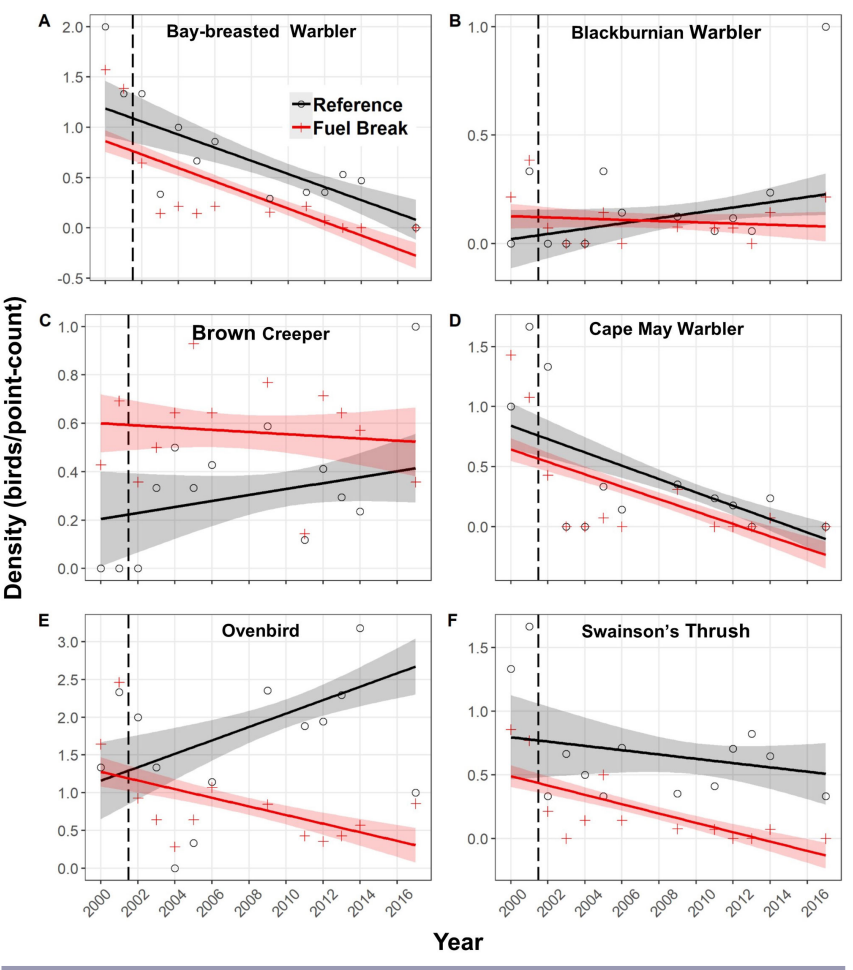

Fig. 4. Responses of forest generalist species to the creation of a community fuel break in Prince Albert National Park, Saskatchewan. Point-count surveys were conducted two years before $(2000,2001)$ and 16 years after (2002-2017) cutting in the fuel break $(n=14)$ and in undisturbed reference sites $(n=$ 3). Additional reference sites from a local bird monitoring project that began in 2006 were also included as reference sites $(\mathrm{n}=14)$. Error bands represent $85 \%$ confidence intervals. The vertical dashed line represents the approximate date the fuel break was constructed. Annual mean abundance values for fuel break and reference sites are shown as crosses and circles, respectively.
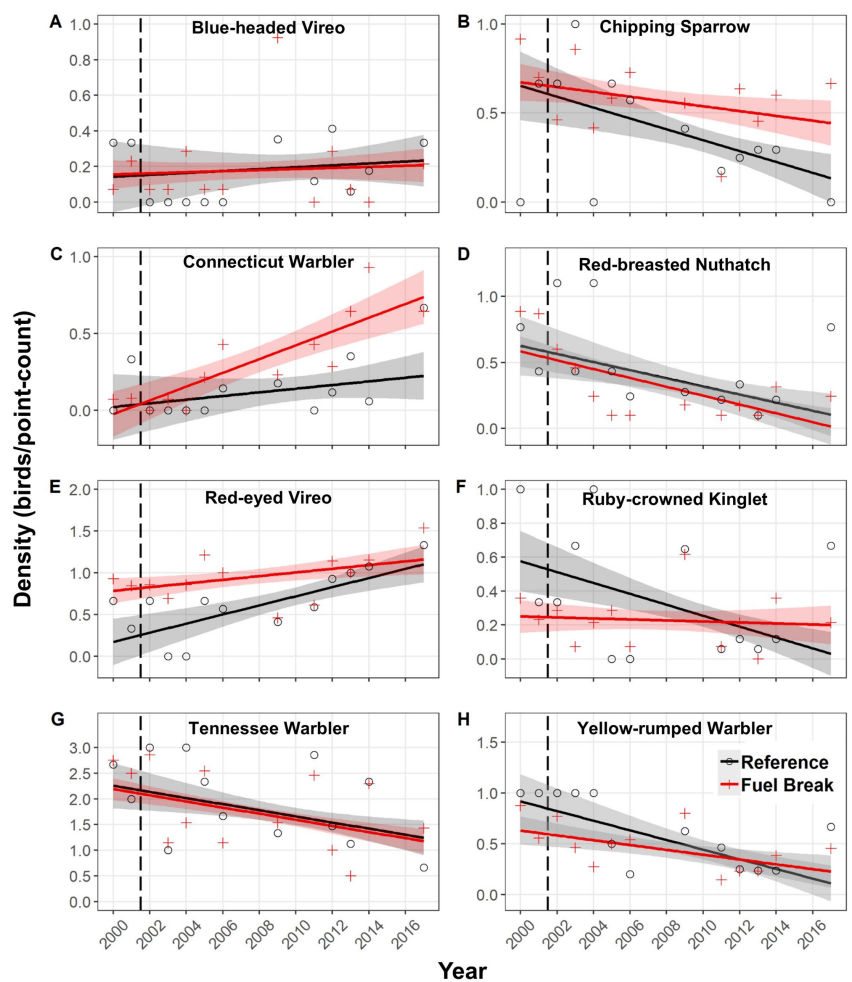
Fig. 5. Responses of open and shrub-dwelling species to the creation of a community fuel break in Prince Albert National Park, Saskatchewan. Point-count surveys were conducted two years before $(2000,2001)$ and 16 years after (2002-2017) cutting in the fuel break $(\mathrm{n}=14)$ and in undisturbed reference sites (n $=3$ ). Additional reference sites from a local bird monitoring project that began in 2006 were also included as reference sites $(\mathrm{n}=14)$. Error bands represent $85 \%$ confidence intervals. The vertical dashed line represents the approximate date the fuel break was constructed. Annual mean abundance values for fuel break and reference sites are shown as crosses and circles, respectively.

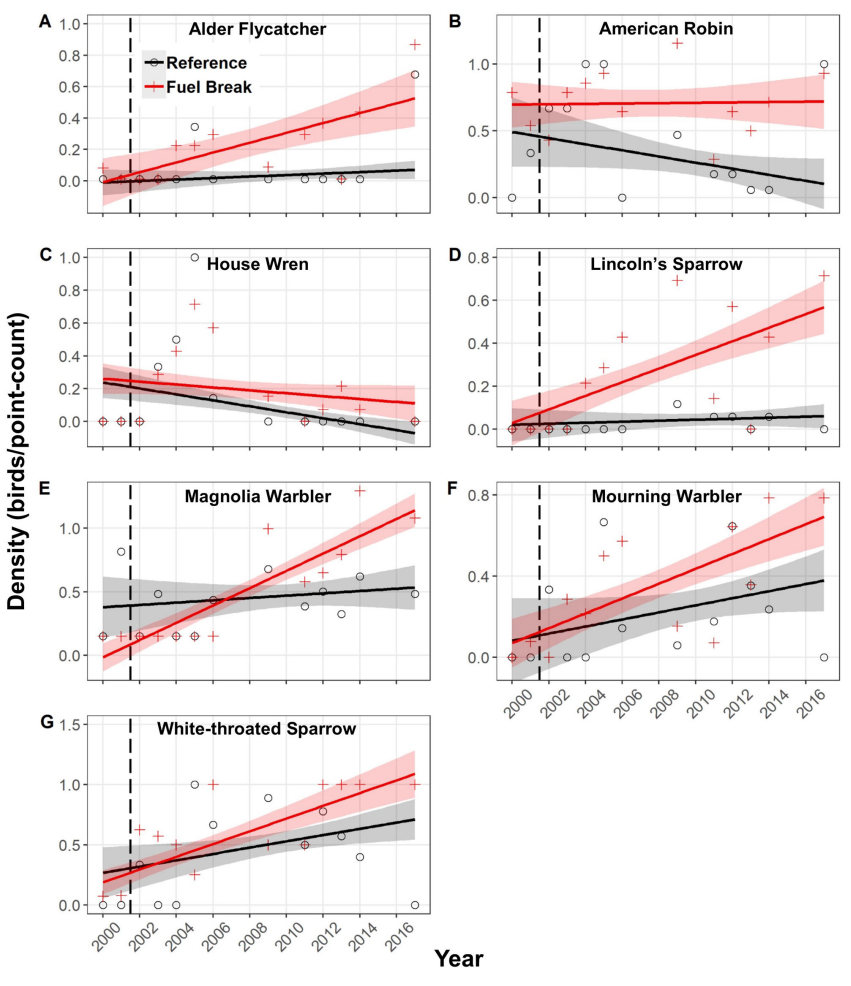

grass-dominated habitat. Similar to our results, shrub-nesting and open habitat bird species typically increase following clear-cut forestry as understory shrubs and saplings dominate the vegetation community (Hobson and Schieck 1999, Harrison et al. 2005, Kardynal et al. 2011). We reason that bird community composition in regenerating fuel breaks and clear-cuts would have divergent trajectories through time due to differences in vegetation succession but this requires additional research (Hobson and Schieck 1999).

Although the fuel break generally had overall high ( $60-90 \%)$ amounts of clearing, our study site encompassed a relatively wide range of forest thinning and other research has indicated some forest-dependent species may persist in landscapes with even low amounts of tree retention (Tittler et al. 2001, Van Wilgenburg and Hobson 2008). Although speculative, maximizing the number of trees or residual patches in fuel breaks may benefit some species sensitive to forest removal and thinning. Different approaches to fuel break design (e.g., feathered thinning) and management may also reduce the impact to species most sensitive to clearing. Retaining residual trees or patches, particularly highly flammable coniferous trees, clearly requires balancing habitat maintenance with the goals of reducing fuel loads in vegetation breaks. However, directed experimental research is required to address these questions

Trends of most species, including forest interior specialists, were generally similar in both fuel break and reference sites. There is a possibility that these trends were the result of regional population trends in 2002 that lasted throughout the duration of our study. However, it is more likely that there were broader-scale impacts on bird density beyond the fuel break area. The presence and structure of forest edges (e.g., higher shrub density) likely influenced bird density in both fuel break and reference sites. Reference sites associated with our study were positioned closer (typically $<200 \mathrm{~m}$ ) to the fuel break than we initially anticipated given original fuel break boundaries, which likely influenced our observed trends. Although having more reference sites and positioning them farther away from the fuel break was preferred, incorporating year and thinning variables into our models was valuable in describing responses to cutting of the fuel break Future studies of bird community change in fuel breaks should consider potential impacts of clearing and maintenance beyond the fuel break boundary.

Several factors make interpretation of results from this study challenging. For instance, having two years of precut data in contrast to many more years postcutting, the small sample size, particularly of reference sites, and changes in detectability before and after harvest (i.e., habitat change) may increase variance in the dataset. Further, our study occurred in a small area in the boreal forest and a lack of replicates (i.e., fuel breaks) may cause issues with spatial and temporal autocorrelation (e.g., annual abundance) and vulnerability to localized stochastic events (e.g., weather). Such effects could mask or exacerbate the results observed in our study potentially limiting our ability to make inferences from this dataset. To minimize the impacts of these factors, we included data from a local bird monitoring program to increase the number of reference sites and accounted for differences in detectability by using QPAD estimates that incorporated habitat (e.g., open vs. forest) and spatial and temporal effects to reduce variance (Sólymos et al. 2013). Further, a lack of fuel breaks elsewhere in the boreal forest precluded investigation of these effects across replicate study areas. Importantly, future studies on fuel breaks should ensure that sufficient uncut reference sites are included for robust comparisons with fuel breaks. However, the abrupt change in forest cover with fuel break construction resulted in immediate and generally expected responses for many species in this study.

Our results nonetheless have several important implications for employing fuel breaks as a management method in boreal forest and protected area landscapes. National parks play an important role in maintaining habitat for many species that may undergo declines due to agricultural or forest management practices that remove old-growth or late seral habitats in managed landscapes. Further, the small area of land designated as protected areas free from direct human disturbance or management in the Boreal Plains Ecozone (Hobson et al. 2002a) illustrates the need for effective management of the remaining forest in a natural state. 
Indeed, a core concern for national parks in Canada and elsewhere is to maintain representative regions of natural biodiversity and the maintenance of unnatural forest stages in the midst of contiguous forest may undermine that objective, especially if other species are able to inhabit these islands (Schmiegelow and Mönkkönen 2002, Parks Canada Agency 2008). A trend toward increasing recreational and commercial usage in and adjacent to national parks will potentially result in an increased requirement to protect human infrastructure. For example, Parks Canada has commenced expansion of the Waskesiu fuel break and creation of a new fuel break to reduce the potential for catastrophic fire damage to commercial properties outside Prince Albert National Park ( 395 ha total new fuel break area; https://www.pc.gc.ca/en/ pn-np/sk/princealbert/visit/pare-feu_amenage-fuel_break), which may be unprecedented in Canada and contradict Parks Canada's mandate of protecting Canada's natural heritage. Reducing the overall size and increasing tree retention within fuel breaks, possibly as islands or patches (Hobson and Schieck 1999) would likely provide an overall benefit for most forest-associated species and should be considered wherever such management would not interfere with the objective of reducing fuel loads.

Responses to this article can be read online at: http://www.ace-eco.org/issues/responses.php/1407

\section{Acknowledgments:}

We thank Parks Canada staff, S. Cherry and D. Guedo, for providing information on management and maintenance of the Waskesiu resort village fuel break, data from Prince Albert National Park's bird monitoring dataset, orthographic images of the fuel break, and in-kind support. Funding for this project was provided by Environment Canada, Canadian Wildlife Service, and Science and Technology.

\section{LITERATURE CITED}

Acton, D. F., G. A. Padbury, and C. T. Stushnoff. 1998. The ecoregions of Saskatchewan. University of Regina Press, Regina, Saskatchewan, Canada.

Agee, J. K., B. Bahro, M. A. Finney, P. N. Omi, D. B. Sapsis, C. N. Skinner, J. W. van Wagtendonk, and C. P. Weatherspoon. 2000. The use of shaded fuelbreaks in landscape fire management. Forest Ecology and Management 127:55-66. https://doi. org/10.1016/S0378-1127(99)00116-4

Bayne, E. M., S. Haché, and K. A. Hobson. 2010. Comparing the predictive capability of forest songbird habitat models based on remotely sensed versus ground-based vegetation information. Canadian Journal of Forest Research 40:65-71. https://doi. org/10.1139/X09-170

Bolker, B. M., and R Development Core Team. 2017. bbmle: tools for general maximum likelihood estimation. $\mathrm{R}$ package version 1.0.20. R Foundation for Statistical Computing, Vienna, Austria. [online] URL: https://CRAN.R-project.org/package=bbmle

Boucher, Y., P. Grondin, and I. Auger. 2014. Land use history (1840-2005) and physiography as determinants of southern boreal forests. Landscape Ecology 29:437-450. https://doi.org/10.1007/ s10980-013-9974-x

Buckland, S. T., D. R. Anderson, K. P. Burnham, J. L. Laake, D. L. Borchers, and L. Thomas. 2001. Introduction to distance sampling estimating abundance of biological populations. Oxford University Press, London, UK.

Burnett, R. D., N. E. Seavy, L. Salas, and D. L. Humple. 2012. Avian community response to mechanical fuel treatment in the Sierra Nevada, USA. PRBO Conservation Science, Petaluma, California, USA. [online] URL: https://data.prbo.org/apps/ snamin/uploads/images/fuels/PRBO $\% 20$ QLG $\% 20$ Fuel $\% 20$ Treatment $\%$ 20Final $\% 20$ Report.pdf

Cade, B. S. 2015. Model averaging and muddled multimodel inferences. Ecology 96:2370-2382. https://doi.org/10.1890/14-1639.1

Campbell, M., and C. M. Francis. 2011. Using stereomicrophones to evaluate observer variation in North American Breeding Bird Survey point counts. Auk 128:303-312. https://doi. org/10.1525/auk.2011.10005

Chape, S., J. Harrison, M. Spalding, and I. Lysenko. 2005. Measuring the extent and effectiveness of protected areas as an indicator for meeting global biodiversity targets. Philosophical Transactions of the Royal Society of London, Series B: Biological Sciences 360:443-455. https://doi.org/10.1098/rstb.2004.1592

Collins, B. M., S. L. Stephens, J. J. Moghaddas, and J. Battles. 2010. Challenges and approaches in planning fuel treatments across fire-excluded forested landscapes. Journal of Forestry 108:24-31. [online] URL: https://www.fs.fed.us/psw/publications/4202/ psw_2010_collins001.pdf

Farnsworth, G. L., K. H. Pollock, J. D. Nichols, T. R. Simons, J. E. Hines, and J. R. Sauer. 2002. A removal model for estimating detection probabilities from point-count surveys. Auk 119:414-425.

Federal, Provincial, and Territorial Governments of Canada. 2010. Canadian biodiversity: ecosystem status and trends 2010. Canadian Councils of Resource Ministers, Ottawa, Ontario, Canada. [online] URL: http://www.biodivcanada.ca/default.asp? lang $=$ En $\& n=83$ A35E06-1\&pedisable $=$ true

Government of Canada. 2000. Canada national parks act. Government of Canada, Ottawa, Ontario, Canada. [online] URL: https://laws-lois.justice.gc.ca/eng/acts/n-14.01/page-1.html

Hansen, M. C., P. V. Potapov, R. Moore, M. Hancher, S. A. Turubanova, A. Tyukavina, D. Thau, S. V. Stehman, S. J. Goetz, T. R. Loveland, A. Kommareddy, A. Egorov, L. Chini, C. O. Justice, and J. R. G. Townshend. 2013. High-resolution global maps of 21st-century forest cover change. Science 342:850-853. https://doi.org/10.1126/science.1244693

Harrison, R. B., F. K. A. Schmiegelow, and R. Naidoo. 2005. Stand-level response of breeding forest songbirds to multiple levels of partial-cut harvest in four boreal forest types. Canadian Journal of Forest Research 35:1553-1567. https://doi.org/10.1139/ $\mathrm{x} 05-076$

Hobson, K. A., and E. M. Bayne. 2000a. Breeding bird communities in boreal forest of western Canada: consequences of "unmixing" the mixedwoods. Condor 102:759-769. https://doi. org/10.2307/1370303 
Hobson, K. A., and E. M. Bayne. 2000b. The effects of stand age on avian communities in aspen-dominated forests of central Saskatchewan, Canada. Forest Ecology and Management 136:121-134. https://doi.org/10.1016/s0378-1127(99)00287-x

Hobson, K. A., E. M. Bayne, and S. L. Van Wilgenburg. $2002 a$. Large-scale conversion of forest to agriculture in the boreal plains of Saskatchewan. Conservation Biology 16:1530-1541. https://doi. org/10.1046/j.1523-1739.2002.01199.X

Hobson, K. A., D. A. Kirk, and A. R. Smith. 2000. A multivariate analysis of breeding bird species of western and central Canadian boreal forests: stand and spatial effects. Écoscience 7:267-280. https://doi.org/10.1080/11956860.2000.11682596

Hobson, K. A., R. S. Rempel, H. Greenwood, B. Turnbull, and S. L. Van Wilgenburg. 2002b. Acoustic surveys of birds using electronic from recordings: potential omnidirectional microphone system. Wildlife Society Bulletin 30:709-720.

Hobson, K. A., and J. Schieck. 1999. Changes in bird communities in boreal mixedwood forest: harvest and wildfire effects over 30 years. Ecological Applications 9:849-863.

Hurteau, S. R., T. D. Sisk, W. M. Block, and B. G. Dickson. 2008. Fuel-reduction treatment effects on avian community structure and diversity. Journal of Wildlife Management 72:1168-1174. https://doi.org/10.2193/2007-351

Kardynal, K. J., J. L. Morissette, S. L. Van Wilgenburg, E. M. Bayne, and K. A. Hobson. 2011. Avian responses to experimental harvest in southern boreal mixedwood shoreline forests: implications for riparian buffer management. Canadian Journal of Forest Research 41:2375-2388. https://doi.org/10.1139/ x11-145

Kelly, R., M. L. Chipman, P. E. Higuera, I. Stefanova, L. B. Brubaker, and F. S. Hu. 2013. Recent burning of boreal forests exceeds fire regime limits of the past 10,000 years. Proceedings of the Academy of Natural Sciences of Philadelphia 110:13055-13060. https://doi.org/10.1073/pnas.1305069110

Linke, J., and G. J. McDermid. 2012. Monitoring landscape change in multi-use west-central Alberta, Canada using the disturbance-inventory framework. Remote Sensing of Environment 125:112-124. https://doi.org/10.1016/j.rse.2012.07.011

Magnusson, A., H. J. Skaug, A. Nielsen, C. W. Berg, K. Kristensen, M. Maechler, K. J. van Bentham, B. M. Bolker, and M. E. Brooks. 2017. glmmTMB: generalized linear mixed models using template model builder. $\mathrm{R}$ package version 0.1.3. $\mathrm{R}$ Foundation for Statistical Computing, Vienna, Austria. [online] URL: https://github.com/glmmTMB

Matsuoka, S. M., E. M. Bayne, P. Sólymos, P. C. Fontaine, S. G. Cumming, F. K. A. Schmiegelow, and S. J. Song. 2012. Using binomial distance-sampling models to estimate the effective detection radius of point-count surveys across boreal Canada. Auk 129:268-282. https://doi.org/10.1525/auk.2012.11190

Michaelian, M., E. H. Hogg, R. J. Hall, and E. Arsenault. 2011. Massive mortality of aspen following severe drought along the southern edge of the Canadian boreal forest. Global Change Biology 17:2084-2094. https://doi.org/10.1111/j.1365-2486.2010.02357. $\mathrm{X}$
National Park Service. 1916. Organic act. US National Park Service, Washington, D.C., USA.

Oksanen, J., F. G. Blanchette, M. Friendly, R. Kindt, P. Legendre, D. McGlinn, P. R. Minchin, R. B. O'Hara, G. L. Simpson, P. Solymos, M. H. H. Stevens, E. Szoecs, and H. Wagner. 2018. vegan: community ecology package. $\mathrm{R}$ package version $2.5-2$. $\mathrm{R}$ Foundation for Statistical Computing, Vienna, Austria. [online] URL: https://cran.r-project.org/web/packages/vegan/index.html

Parks Canada Agency. 2008. Action on the ground II: working with Canadians to improve ecological integrity in Canada's national parks. Parks Canada Agency, Ottawa, Ontario, Canada. [online] URL: https://www.pc.gc.ca/en/docs/v-g/ie-ei/at-ag/ / media/8D197E5169C54653814D48411DFEE302.ashx

Peng, C., Z. Ma, X. Lei, Q. Zhu, H. Chen, W. Wang, S. Liu, W. Li, X. Fang, and X. Zhou. 2011. A drought-induced pervasive increase in tree mortality across Canada's boreal forests. Nature Climate Change 1:467-471. https://doi.org/10.1038/nclimate1293

Prince Albert National Park. 2000. Plan for the Waskesiu community fuel break. Prince Albert National Park, Waskesiu, Saskatchewan, Canada.

R Core Team. 2018. R: A language and environment for statistical computing. 3.5.0 edition. The $\mathrm{R}$ Foundation for Statistical Computing, Vienna, Austria. URL: https://www.R-project.org/

Sanderson, L. A., J. A. McLaughlin, and P. M. Antunes. 2012. The last great forest: a review of the status of invasive species in the North American boreal forest. Forestry 85:329-340. https:// doi.org/10.1093/forestry/cps033

Schmiegelow, F. K. A., and M. Mönkkönen. 2002. Habitat loss and fragmentation in dynamic landscapes: avian perspectives from the boreal forest. Ecological Applications 12:375-389.

Sólymos, P., S. M. Matsuoka, E. M. Bayne, S. R. Lele, P. Fontaine, S. G. Cumming, D. Stralberg, F. K. A. Schmiegelow, and S. J. Song. 2013. Calibrating indices of avian density from nonstandardized survey data: making the most of a messy situation. Methods in Ecology and Evolution 4:1047-1058. https://doi. org/10.1111/2041-210X.12106

Syphard, A. D., V. C. Radeloff, J. E. Keeley, T. J. Hawbaker, M. K. Clayton, S. I. Stewart, and R. B. Hammer. 2007. Human influence on California fire regimes. Ecological Applications 17:1388-1402. https://doi.org/10.1890/06-1128.1

ter Braak, C. J. F., and P. Smilauer. 2002. CANOCO reference manual and CanoDraw for Windows user's guide: software for canonical community ordination (version 4.5). Microcomputer Power, Ithaca, New York, USA.

Tittler, R., S. J. Hannon, and M. R. Norton. 2001. Residual tree retention ameliorates short-term effects of clear-cutting on some boreal songbirds. Ecological Applications 11:1656-1666. [online] URL: https://era.library.ualberta.ca/items/c41dfcf4-2b62-4300befc-2b0c84888ade/download/cddf0cla-8936-4287-82fa-b963911f5fla

van den Brink, P. J., and C. J. F. ter Braak. 1999. Principal response curves: analysis of time-dependent multivariate responses of biological community to stress. Environmental Toxicology and Chemistry 18:134-148. https://doi.org/10.1002/etc.5620180207 
Van Wilgenburg, S. L., and K. A. Hobson. 2008. Landscape-scale disturbance and boreal forest birds: can large single-pass harvest approximate fires? Forest Ecology and Management 256:136-146. https://doi.org/10.1016/j.foreco.2008.04.017

Venier, L. A., and S. B. Holmes. 2010. A review of the interaction between forest birds and eastern spruce budworm. Environmental Reviews 18:191-207. https://doi.org/10.1139/A10-009

Warton, D. I. 2005. Many zeros does not mean zero inflation: comparing the goodness-of-fit of parametric models to multivariate abundance data. Environmetrics 16:275-289. https:// doi.org/10.1002/env.702

Wells, J. V. 2011. Boreal birds of North America: a hemispheric view of their conservation links and significance. University of California Press, Oakland, California, USA.

Wood, E. M., A. M. Pidgeon, V. C. Radeloff, D. Helmers, P. D. Culbert, N. S. Keuler, and C. H. Flather. 2014. Housing development erodes avian community structure in U.S. protected areas. Ecological Applications 24:1445-1462. https://doi. org/10.1890/12-1992.1

Wood, E. M., A. M. Pidgeon, V. C. Radeloff, D. P. Helmers, P. D. Culbert, N. S. Keuler, and C. H. Flather. 2015. Long-term avian community response to housing development at the boundary of US protected areas: effect size increases with time. Journal of Applied Ecology 52:1227-1236. https://doi.org/10.1111/1365-2664.12492 